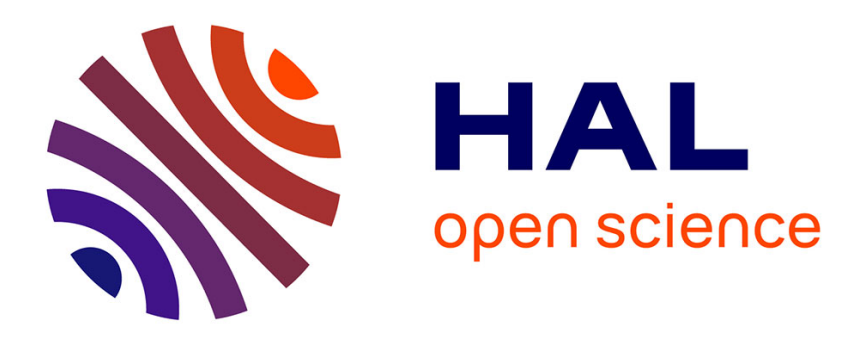

\title{
Studies on thermal performances of a new greenhouse cladding material
}

Shaojin Wang, Jules Deltour

\section{To cite this version:}

Shaojin Wang, Jules Deltour. Studies on thermal performances of a new greenhouse cladding material. Agronomie, 1999, 19 (6), pp.467-475. hal-00885945

\section{HAL Id: hal-00885945 https://hal.science/hal-00885945}

Submitted on 1 Jan 1999

HAL is a multi-disciplinary open access archive for the deposit and dissemination of scientific research documents, whether they are published or not. The documents may come from teaching and research institutions in France or abroad, or from public or private research centers.
L'archive ouverte pluridisciplinaire HAL, est destinée au dépôt et à la diffusion de documents scientifiques de niveau recherche, publiés ou non, émanant des établissements d'enseignement et de recherche français ou étrangers, des laboratoires publics ou privés. 
(C) Inra/Elsevier, Paris

\title{
Original article
}

\section{Studies on thermal performances of a new greenhouse cladding material}

\author{
Shaojin Wang ${ }^{\mathrm{a}^{*}}$, Jules Deltour ${ }^{\mathrm{b}}$ \\ "Unité de bioclimatologie, Inra, Site Agroparc, domaine Saint-Paul, 84914 Avignon cedex 9, France \\ ${ }^{b}$ Unité de physique et chimie physique, faculté universitaire des sciences agronomiques, \\ 8, avenue de la Faculté, B-5030 Gembloux, Belgium
}

(Received 10 November 1998; accepted 8 April 1999)

\begin{abstract}
Cladding material is one of the most important parts of a greenhouse. Thermal performances of a new bioriented corrugated rigid sheet of polyvinyl chloride (PVC) were studied by spectral measurements and dynamic simulations. Analysis of the data based on the experimental spectral values led to a first improvement by a $5 \%$ relative increase in the PAR transmittance. Further studies on thermal performances of the new PVC sheet with four other similar materials were performed by a dynamic energy balance model in both passive and active greenhouses over six months. The simulation results showed that an 'ideal' PVC sheet with low emittance in thermal infrared radiation would reduce the annual heat load by $21 \%$. ( $\odot$ Inra/Elsevier, Paris.)
\end{abstract}

\section{greenhouse / cladding materials / model / simulation}

Résumé - Étude des propriétés thermiques d'un nouveau matériau de couverture d'une serre. Le matériau de couverture est le composant essentiel d'une serre. Les propriétés thermiques d'un nouveau chlorure de polyvinyle (PVC) biorienté en plaques ondulées rigides ont été étudiées à partir de mesures spectrales et de simulations dynamiques. L'analyse des résultats des mesures spectrales a permis une première amélioration grâce à une augmentation relative de $5 \%$ du facteur de transmission du PAR. De plus, des études comparatives des propriétés thermiques du nouveau PVC en plaque avec quatre autres matériaux ont été effectuées à l'aide d'un modèle du bilan énergétique dynamique dans des serres passive et active sur une periode de 6 mois. Les résultats des simulations ont montré qu'un PVC idéal avec une faible émissivité dans l'infrarouge thermique réduirait de $21 \%$ la consommation énergétique annuelle. (CInra/Elsevier, Paris.)

serre / matériau de couverture / modèle / simulation

Communicated by John E. Sheehy (Manila, Philippines)

* Correspondence and reprints

wang@avignon.inra.fr 


\section{Introduction}

Greenhouse cladding material has to meet contradictory requirements: its radiometric properties have to include a large value of transmittance for solar radiation and, in particular the PAR domain, and a low value for the thermal infrared radiation. In recent years, many new cladding materials have appeared on the market without detailed technical information on their optical properties. The users have then had some difficulties in selecting and comparing them. Moreover, it is difficult to test a new cladding material under field conditions because it takes a long time and the results obtained depend on local climate. Therefore, careful laboratory measurements and dynamic simulations offer alternative methods for studying thermal performances of a new greenhouse cladding material.

Dynamic simulation is regarded as one of the most powerful methods used for understanding the complex mechanism of heat and mass transfers in greenhouses. Since 1970, a number of dynamic climate models have been developed $[3,5,11,24$, 25]. Among them, the GGDM (Gembloux Greenhouse Dynamic Model) has been validated in small tunnels [26] and large-scale greenhouses [21] located in Gembloux (Belgium), Quebec (Canada) and Dorst (The Netherlands) $[4,21,26]$, with thermal screens [20] and in the presence of condensation on cladding materials [19] for a long time. The high accuracy and reliability of the GGDM allowed us to use it for analysing thermal performances of various greenhouse cladding materials.

The radiometric properties of cladding materials are characterised by their coefficients of transmit tance, reflectance and absorption to the radiation [13]. Direct measurement of the transmittance and reflectance for a given material was performed for the different spectral domains considered [7], using a large number of samples [15].

The thermal properties of different cladding materials were investigated using three methods: theoretical models $[9,14]$, a hot box method [8] and greenhouse experiments [1, 22, 27]. Extensive investigations on greenhouses with thermal screens have shown a decrease in energy consumption [2, $10,12]$ and light $[15,17,20]$, and an increase in humidity $[2,16]$ accompanied by a decrease in the production and the quality of the products [23].

For improved cladding materials, some contradictory needs must be satisfied: good transmittance in the solar spectrum and good durability from anti$\mathrm{UV}$ additives reducing the light transmittance; and low thermal loss from a low transmittance in the thermal infrared domain. The major objectives of this study were a) to perform a series of radiometric spectral measurements on a new cladding material delivered by a manufacturer for various ranges of wavelengths and incidence angles, and b) to improve the solar transmittance in the PAR domain. Secondary objectives were a) to test the thermal performances of the new cladding material and the effect of the reduction of the surface emittance in thermal infrared radiation, and b) to validate the results obtained using a dynamic greenhouse climate model running over a 6 -month period.

\section{Materials and methods}

\subsection{Primary measurement}

The new cladding material evaluated was a polyvinyl chloride, bi-oriented and corrugated sheet (PVC, 0.001 $\mathrm{m}$ thick). For a comparison, four other cladding materials were used in the dynamic simulation: standard glass (glass, $0.004 \mathrm{~m}$ ), polymethyl methacrylate (PMMA, $0.002 \mathrm{~m}$ ), polycarbonate (PC, $0.0012 \mathrm{~m}$ ) and an ideal polyvinyl chloride sheet' $\left(\mathrm{PVC}_{\mathrm{id}}, 0.001 \mathrm{~m}\right)$. This ideal material does not exist on the market, but should have a good transparency in the solar spectrum and a low emittance in the thermal infrared. Previous research work [14] has shown that a low-emittance coating glass induces a significant improvement in energy saving. The ideal material adopted as a reference was chosen to have the same spectral properties as PVC in the solar spectrum and a thermal emittance equal to 0.50 .

A cladding material must be characterised for different wavelength domains, for different irradiances and for various incidence angles. This should be based on spectral measurements over the entire wavelength $(\lambda$, $\mathrm{nm})$ ranges [15]. The measurement system includes a spectral source, a monochromator and a receiver. For 
this study, a goniometric system allowed variations in the incidence angle and an integrating sphere collected the radiation diffused by the sample. This classical method was used to measure both the transmittance $\tau(\lambda)$ and reflectance $\rho(\lambda)$ of the sample for incidence angles of $0,15,30,45$ and $60^{\circ}$. The values for the incidence angle $\alpha=75^{\circ}$ were obtained by interpolation between the measured values at $60^{\circ}$ and the limit values at $90^{\circ}$ $\left(\rho_{90}=1, \tau_{90}=0\right)$. These spectral angular measurements were carried out for the solar spectrum. Only normal incidence was investigated for the thermal infrared radiation. Detailed information about different radiation sources is presented in Appendix A.

\subsection{Dynamic simulation}

\subsubsection{Description of the model}

Dynamic simulation is one of the most important tools for understanding thermal behaviours of greenhouses [11]. The present study was carried out on the basis of the GGDM $[4,5]$, which has been used to analyse climatic characteristics in greenhouse for long periods.

The model is a classical one-dimensional thermodynamic model that allows the calculation of the dynamic energy balance of each greenhouse component (fig- ure l): the cover (c), the interior air (i), the vegetation (v) and three-soil layers (s1, s2 and s3). The interactions between the six layers considered include heat transfers by conduction (D), convection (V), solar (S) and thermal $(R)$ radiation as well as latent heat exchanges $(\mathrm{L})$. Therefore, six energy balance equations çan be established to solve six unknown temperatures by an iterative procedure. As an example, the energy balance equation for the internal air is given by:

$$
C_{\mathrm{a}} \cdot \frac{V O L}{A_{t}} \cdot \frac{d t}{d t}=V_{v, i}-V_{i, c}-V_{i, s}-V_{i, e}-Q_{i n}
$$

where $C_{a}$ is the heat capacity per unit volume of air $\left(\mathrm{J} \mathrm{m}^{-3} \mathrm{~K}^{-1}\right)$; VOL is the greenhouse volume $\left(\mathrm{m}^{3}\right)$; $\mathrm{A}_{\mathrm{t}}$ is the greenhouse ground area $\left(\mathrm{m}^{2}\right) ; \mathrm{T}_{i}$ is the internal air temperature $(\mathrm{K}) ; \mathrm{t}$ is the time $(\mathrm{s}) ; \mathrm{V}_{\mathrm{j}, \mathrm{k}}$ is the convective heat flux density between elements $\mathrm{j}$ and $\mathrm{k}\left(\mathrm{W} \mathrm{m}^{-2}\right)$; and $Q_{\text {in }}$ is the heat energy input $\left(\mathrm{W} \mathrm{m}^{-2}\right)$.

Two types of greenhouses were investigated: a passive greenhouse in which the air temperature depends on the balance of convective heat fluxes, as expressed in equation (1) when no heat energy is input $\left(Q_{\text {in }}=0\right)$, and an active type where the heating load contributes to the overall thermal equilibrium to keep the air temperature at a pre-set point.

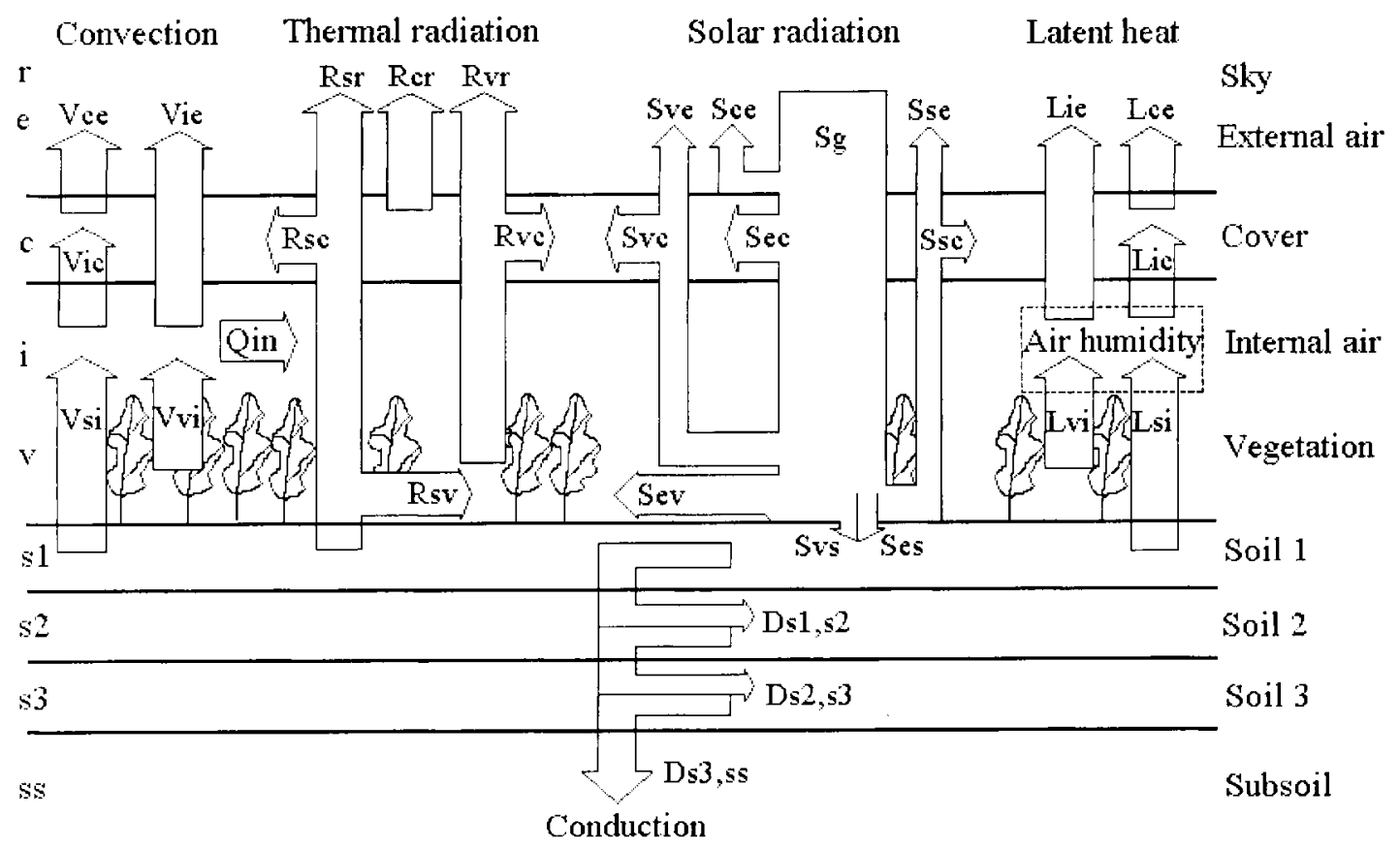

Figure 1. Diagram of the heat transfer fluxes in the greenhouse energy balance model (the symbols are listed in Appendix B). 


\subsubsection{Validation of the model}

The GGDM has been calibrated and validated against a large number of experimental parameters in different greenhouses, under various weather conditions $[3,21$, 26]. The validation of the GGDM showed that the mean deviation between measured and calculated air temperatures was less than $1{ }^{\circ} \mathrm{C}$ with a standard deviation less than $1.5^{\circ} \mathrm{C}$ for the passive greenhouses. For the active greenhouses, the instantaneous heating load was predicted within $\pm 10 \%$. A detailed description of the GGDM calibration and validation can be found in de Halleux et al. [4].

\subsubsection{Simulation conditions}

The simulation period from 15 December to 14 June was selected because it corresponds to the period of a complete tomato cultivation cycle in greenhouses in Belgium. This period includes a variety of external climatic conditions: cold and hot days, clear and cloudy skies, windy and calm days, etc. These external climatic conditions were selected from the so-called 'typical reference year' established by Dogniaux et al. [6]. The 'simulation' greenhouse was located at latitude $51.48^{\circ} \mathrm{N}$ (Gembloux, Belgium). The total length and width were 48 and $44.8 \mathrm{~m}$, respectively. The heating system used ground and apex pipes. A tomato crop was grown on rockwool in the greenhouse using the substrate culture. The maximum and leakage ventilation rates of the greenhouse were 40 and $0.5 \mathrm{~h}^{-1}$ (number of times greenhouse air volume renewed per hour). The subsoil (ss) temperature was chosen as 10 and $17{ }^{\circ} \mathrm{C}$ for the passive and active greenhouses.

The GGDM includes the heating system and the forced or natural ventilation and their regulation procedures. The regulation was realised by a four-step temperature set point during four periods of the day. These four periods were related to the time of sunrise $(\mathrm{p} 1, \mathrm{p} 2)$ and sunset $(\mathrm{p} 3, \mathrm{p} 4)$ (table I). These temperature set points were different for the four periods which were taken from Pirard et al. [21]. When the global solar radiation flux density was below $200 \mathrm{~W} \mathrm{~m}^{-2}$, the temperature set point was maintained at the same level as indicated in table 1 . However, this temperature set point was raised $2{ }^{\circ} \mathrm{C}$ if the global solar radiation flux density was larger than $500 \mathrm{~W} \mathrm{~m}^{-2}$. Between 200 and $500 \mathrm{~W} \mathrm{~m}^{-2}$ of global solar radiation flux density, the temperature set point was linearly interpolated. Figure 2 gives an example of the temperature set point evolution for heating and ventilation on 17 March.

Vegetation contributed an important part of the sensible and latent heat balances. The characteristics of the vegetation had to be regularly modified by taking into
Table I. Four-step temperature set points for heating and ventilation (after Pirard et al. [21]).

\begin{tabular}{cccc}
\hline Periods & $\begin{array}{c}\text { Start time } \\
\text { of periods (hours) }\end{array}$ & $\begin{array}{c}\text { Heating } \\
\left({ }^{\circ} \mathrm{C}\right)\end{array}$ & $\begin{array}{c}\text { Ventilation } \\
\left({ }^{\circ} \mathrm{C}\right)\end{array}$ \\
\hline p1 & sunrise (-1) & 18 & 18 \\
p2 & sunrise (0) & 19 & 20 \\
p3 & sunset (-1) & 16 & 16 \\
p4 & sunset (+6) & 17.5 & 18 \\
\hline
\end{tabular}

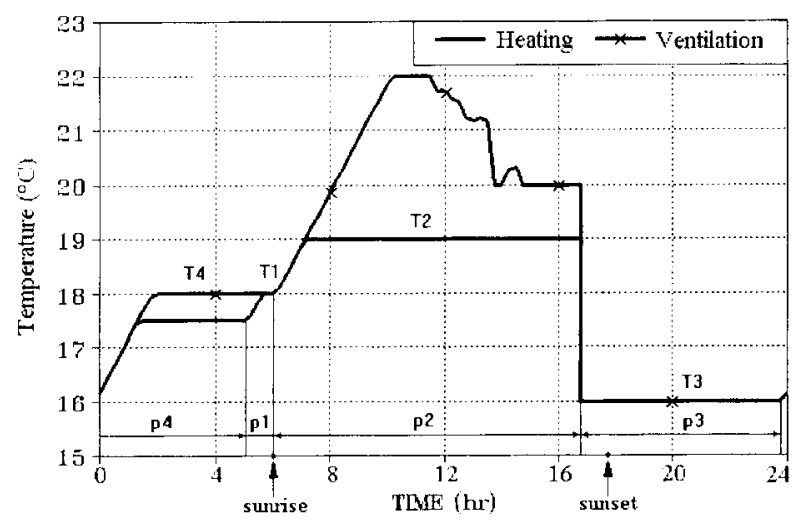

Figure 2. An example of temperature set point on 17 March.

account the growth over the 6-month period. In our simulation, the estimated proportion of ground area covered by crops $\left(P_{v}\right)$, leaf area index (LAI), expressed as leaf area per ground area, and surface mass density $\left(\mathrm{M}_{\mathrm{v}}\right)$ varied as a function of the simulation time (figure 3 ), and approximated the measurement data taken in the experimental greenhouse [21].

\section{Results and discussion}

\subsection{Radiometric property}

Figure 4 shows the measurement results for an initial sample of $\mathrm{PVC}$ rigid sheet $\left(\mathrm{PVC}_{\mathrm{o}}\right)$ in the solar spectrum. The spectral transmittance exhibited an abnormal behaviour in the PAR domain: the transmittance of $\mathrm{PVC}_{\mathrm{O}}$ was lower on the restricted PAR domain than in the total solar spectrum. This situation was unsatisfactory for the marketing 


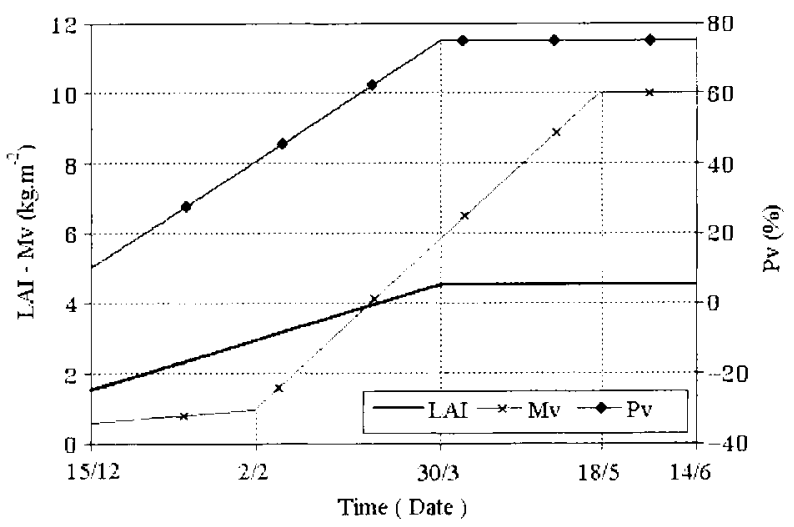

Figure 3. Evolution of vegetation parameters as a function of simulation period (LAI, leaf area index; $\mathrm{P}_{\mathrm{v}}$, portion of ground area covered by crops; $M_{v}$, surface mass density of vegetation).

department which wanted to have products suitable for the horticultural market.

This problem was passed on to the manufacturer and after research into the production process, it was found that the problem was due to the presence of some specific anti-UV additives in the substrate. Therefore, a modification of the anti-UV additives was introduced.

The transmittance in the solar spectrum for a new sample of PVC $\left(\mathrm{PVC}_{\mathrm{n}}\right)$ is also shown in figure 4. This modification of the choice of the additives allowed an increase in the PAR transmittance from 0.83 to 0.88 , a substantial improvement for horticultural purposes.

\subsection{Dynamic simulation results}

The radiometric properties of the different cladding materials such as the new PVC sheet, glass, PMMA, PC, and 'ideal PVC' were determined as indicated in table II. These data were used in the simulation for determining the thermal characteristics of the 'simulation' greenhouse with the different cladding materials. The simulation was performed for various climatic conditions and included the effect of the greenhouse structure, solar irradiance and tomato crop growth.

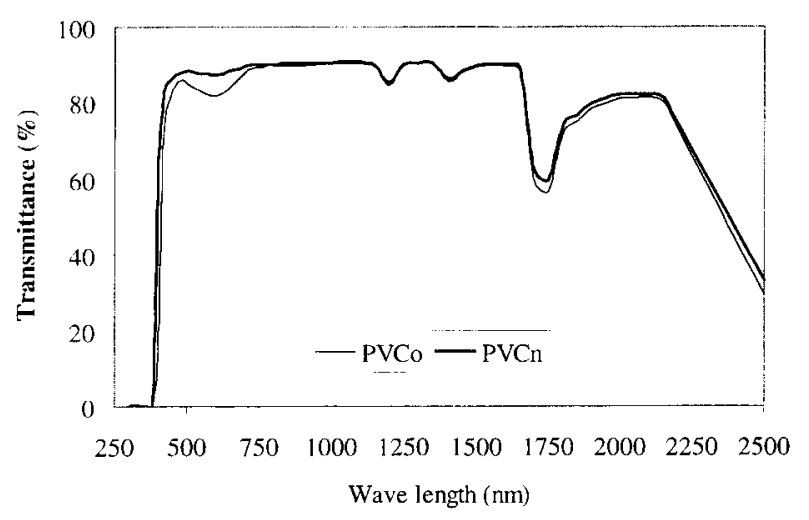

Figure 4. Angular (0: normal incidence) spectral transmittance for a PVC rigid plate in the solar spectrum before $\left(\mathrm{PVC}_{\mathrm{o}}\right)$ and after $\left(\mathrm{PVC}_{\mathbf{n}}\right)$ simulation.

The dynamic simulation showed that for a passive PVC-covered greenhouse, the diurnal mean internal air temperature was higher than the external temperature (figure 5) except for the last 20 days when the internal air temperature was controlled by forced ventilation to reach the required set point. The lowest internal air temperature appeared on 8 January when the outside temperature was at a minimum.

For an active PVC-covered greenhouse, the diurnal mean heat flux density is presented in figure 6 . During the last 20 days the heat input flux was nearly zero due to the high outside air temperature. It should be noted that the heat flux on 22 March was higher than that on 8 January. The reason was that on 8 January, the heat input flux was mainly lost by convection from air to the cover $(56 \%)$ and to the vegetation ( $31 \%$ ); but on 22 March, the heat input flux was transferred by the crop transpiration $(70 \%)$ and by heat convection to the cover $(22 \%)$ owing to crop growth. The results give a useful series of data for the design and the management of a greenhouse heating system.

Table III gives the average simulation results in both passive and active greenhouses, under different cladding materials, from 15 December to 14 June for the 'typical reference year'. For passive greenhouses, the mean internal air temperature 
Table II. Radiometric properties of the tested cladding materials (all parameters are dimensionless).

\begin{tabular}{ccccccccccc}
\hline \multicolumn{1}{c}{} & \multicolumn{9}{c}{ Direct solar radiation at different incidences } & \multicolumn{3}{c}{$\begin{array}{c}\text { Diffuse solar } \\
\text { radiation }\end{array}$} & $\begin{array}{c}\text { Thermal infrarel } \\
\text { radiation }\end{array}$ \\
\hline \multirow{2}{*}{ PVC } & $\tau$ & 0.86 & 0.86 & 0.86 & 0.84 & 0.75 & 0.38 & 0.00 & 0.71 & 0.01 \\
& $\rho$ & 0.08 & 0.08 & 0.08 & 0.10 & 0.18 & 0.59 & 1.00 & 0.14 & 0.05 \\
Glass & $\tau$ & 0.84 & 0.84 & 0.84 & 0.82 & 0.75 & 0.37 & 0.00 & 0.78 & 0.00 \\
& $\rho$ & 0.08 & 0.08 & 0.08 & 0.09 & 0.16 & 0.58 & 1.00 & 0.14 & 0.10 \\
PMMA & $\tau$ & 0.88 & 0.88 & 0.88 & 0.86 & 0.78 & 0.39 & 0.00 & 0.74 & 0.00 \\
& $\rho$ & 0.07 & 0.07 & 0.07 & 0.09 & 0.16 & 0.58 & 1.00 & 0.13 & 0.07 \\
PC & $\tau$ & 0.86 & 0.86 & 0.86 & 0.84 & 0.75 & 0.38 & 0.00 & 0.71 & 0.01 \\
& $\rho$ & 0.08 & 0.0 & 0.09 & 0.11 & 0.19 & 0.60 & 1.00 & 0.15 & 0.09 \\
PVC & $\tau$ & 0.86 & 0.86 & 0.86 & 0.84 & 0.75 & 0.38 & 0.00 & 0.71 & 0.01 \\
& $\rho$ & 0.08 & 0.08 & 0.08 & 0.10 & 0.18 & 0.59 & 1.00 & 0.14 & 0.49 \\
\hline
\end{tabular}

PVC: polyvinyl chloride sheet; PMMA: polymethyl methacrylate; $\mathrm{PC}$ : polycarbonate; $\mathrm{PVC}_{\mathrm{id}}$; ideal polyvinyl chloride sheet; $\tau$ : transmittance; $\rho$ : reflectance.

Solar radiation: $300-2500 \mathrm{~nm}$; far infrared radiation: $2.5-40 \mu \mathrm{m}$.

Table III. Mean thermal performances of cladding materials over 6 months.

\begin{tabular}{lccccc}
\hline Materials & PVC & Glass & PMMA & PC & PVC $_{\text {id }}$ \\
\hline $\begin{array}{l}\text { Passive greenhouse } \\
\text { Mean air temperature during the night }\left({ }^{\circ} \mathrm{C}\right)\end{array}$ & 9.2 & 9.3 & 9.3 & 9.3 & 10.3 \\
Mean air temperature during the day $\left({ }^{\circ} \mathrm{C}\right)$ & 11.5 & 11.6 & 11.7 & 11.6 & 12.5 \\
& & & & & \\
Active greenhouse & 224 & 216 & 219 & 220 & 180 \\
Total heat load during the night $\left(\mathrm{kW} \mathrm{h} \mathrm{m}^{-2}\right)$ & 322 & 310 & 314 & 317 & 257 \\
Total heat load during the day $\left(\mathrm{kW} \mathrm{h} \mathrm{m}^{-2}\right)$ & 104 & 100 & 101 & 102 & 83 \\
Total heat load during the day $(\%)$ & 100
\end{tabular}

PVC: polyvinyl chloride sheet; PMMA: polymethyl methacrylate; PC: polycarbonate; $\mathrm{PVC}_{\mathrm{id}}$ : ideal polyvinyl chloride sheet.

under $\mathrm{PVC}_{\mathrm{id}}$ was the highest one and the new cladding material PVC was equivalent to glass, PMMA and PC. For active greenhouses, the mean heat load was presented under different cladding materials and a percentage of diurnal mean heat load referred to glass was also provided. $\mathrm{PVC}_{\mathrm{id}}$ provided a $17 \%$ energy saving compared with glass.

\section{Conclusions}

The series of spectral measurements provided by this study are very useful for the analysis of the global radiometric properties of a greenhouse. The depression in the transmittance curve that appeared in the PAR region allowed a well-targeted action leading to a $5 \%$ relative improvement in PAR transmittance.

The GGDM was a useful tool for analysing and comparing the thermal performances of different cladding materials. It can provide an inexpensive means of predicting the heat load in greenhouses.

The dynamic simulation results confirmed that $\mathrm{PVC}_{\text {id }}$ was an effective solution to reduce the heat consumption by increasing the reflectance in farinfrared radiation. This reduced emittance could probably be reached by using some new coating on the material. Research results are now being applied by the manufacturer. 


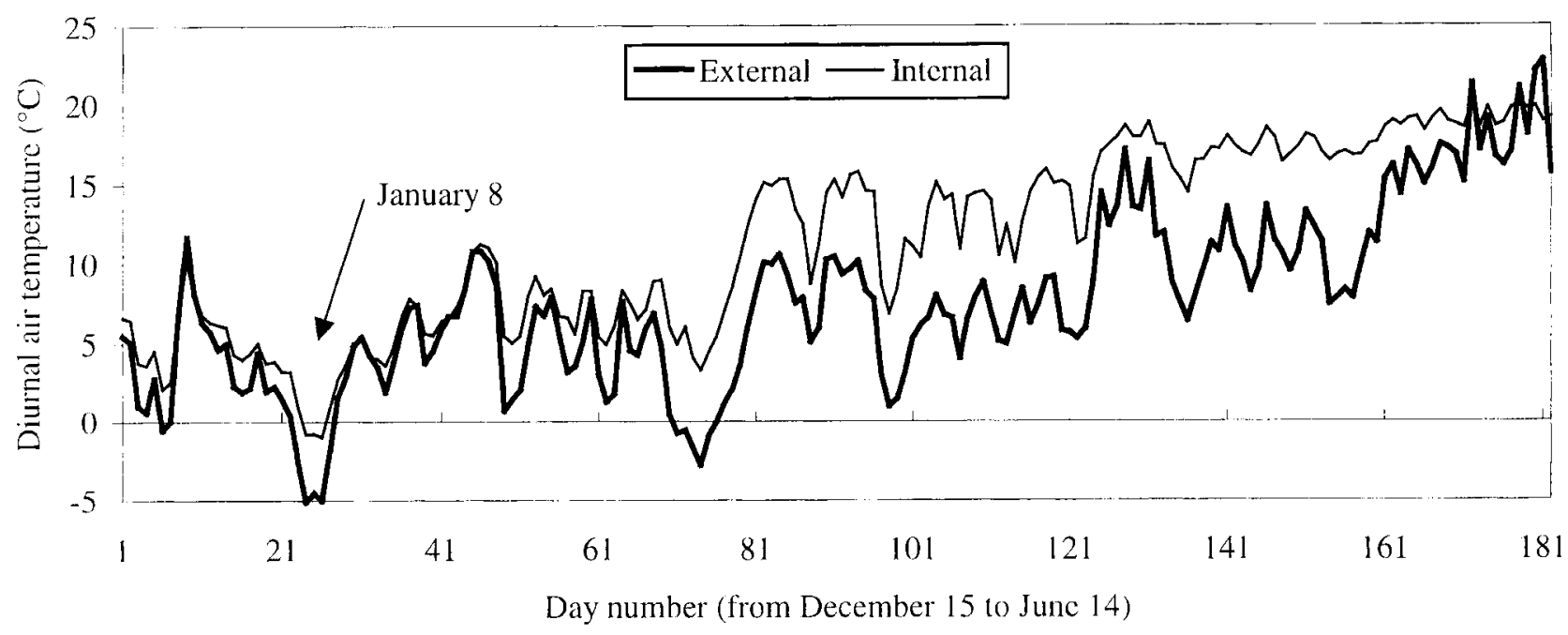

Figure 5. Diurnal mean values of measured external and simulated internal air temperatures in a passive PVC-covered greenhouse over 6 months.

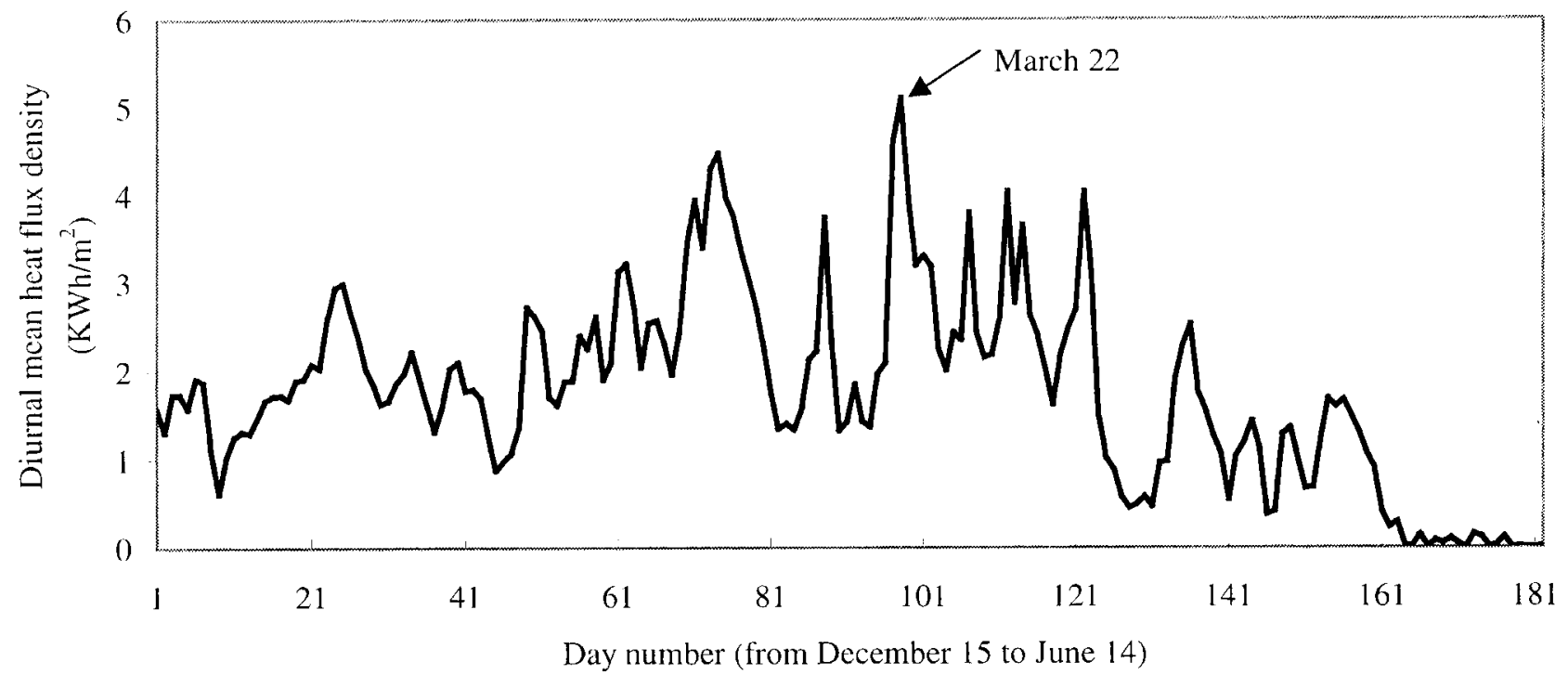

Figure 6. Diurnal mean values of heat input flux density in an active PVC-covered greenhouse over 6 months.

\section{References}

[1] Albright L.D., Seginer I., Marh L.S., Oko A., In situ thermal calibration of unventilated greenhouse, $\mathrm{J}$. Agric. Eng. Res. 31 (1985) 265-281.
[2] Bailey B.J., Experiences with thermal screens in glasshouses on commercial nurseries in England, Plasticulture 50 (1981) 13-22.

[3] De Halleux D., Modèle dynamique des échanges énergétiques des serres: étude théorique et expérimen- 
tale, Ph.D. thesis, faculté des sciences agronomiques de Gembloux, Belgique, 1989, pp. 105-220.

[4] De Halleux D., Nijskens J., Deltour J., Adjustment and validation of a greenhouse dynamic model, Bull. Rech. Agron. Gembloux 26 (1991) 429-453.

[5] Deltour J., De Halleux D., Nijskens J., Coutisse S., Nisen A., Dynamic modeling of heat and mass transfer in greenhouses, Acta Hortic. 174 (1985) 119-126.

[6] Dogniaux R., Lemoine M., Sneyers R., Annéetype moyenne pour le traitement de problèmes de captation d'énergie solaire, Inst. R. Météorol. Belg., Misc. Sér. B, no. 45, 1978, pp. 1-48.

[7] Duffie J.A., Beckman W.A., Solar Engineering of Thermal Processes, John Wiley, New York, 1980, pp. 201-562.

[8] Feuilloley P., Issanchou G., Greenhouse covering materials measurement and modelling of thermal properties using the hot box method and condensation effects, J. Agric. Eng. Res. 65 (1996) 129-142.

[9] Issanchou G., Energetic modeling of greenhouses: setting up of a thermal engineering software, Ph.D. thesis, University of Perpignan, 1991.

[10] Jolliet O., Modélisation du comportement thermique d'une serre horticole, thèse, no. 713, Lausanne, Switzerland, 1988.

[11] Kindelan M., Dynamic modeling of greenhouse environment, Trans. ASAE 23 (1980) 1232-1231.

[12] Marsh L.S., Albright L.D., Langhans R.W., Strategies for controlling greenhouse thermal screens, Acta Hortic. 148 ( 1984) 453-459.

[13] Mermier M., Baille A., The optical properties of plastics materials for greenhouses and screens, Plasticulture 77 (1988) 11-24.

[14] Nijskens J., Deltour J., Coutisse S., Nisen A., Heat transfer through covering materials of greenhouses, Agric. For. Meteorol. 33 (1984) 193-214.

[15] Nijskens J., Deltour J., Coutisse S., Nisen A., Radiation transfer through covering materials, solar and thermal screens of greenhouses, Agric. For. Meteorol. 35 (1985) 229-242.

[16] Nisen A., Coutisse S., Photometric properties of double wall plastics used as covering for greenhouses, Acta Hortic. 115 (1981) 85-97.

[17] Okada M., An analysis of thermal screen effects on greenhouse environment by means of a multi-layer screen model, Acta Hortic. 174 (1985) 139-144.
[18] Papadakis G., Frangoudakis A., Kyttitsis S., Mixed, forced and free convection heat transfer at the greenhouse cover, J. Agric. Eng. Res. 51 (1992) 191-205.

[19] Pieters J.G., Deltour J.M., Performances of greenhouses with the presence of condensation on claddinf materials, J. Agric. Eng. Res. 68 (1997) 125-137.

[20] Pirard G., Deltour J., Nijskens J., Controlled operation of thermal screens in greenhouses, Plasticulture 103 (1994) 11-22.

[21] Pirard G., Vancayemberg F., Deltour J., Rapport d'activités de décembre 1993, Center d'étude de la régulation climatique des serres, Gembloux (Belgique), 1993, pp. 15-70.

[22] Seginer I., Kantz D., In situ determination of transfer coefficient for heat and water vapor in a small greenhouse, J. Agric. Eng. Res. 35 (1986) 39-54.

[23] Steinbuch F., de Vooren V., Production and quality of cutflowers and potplants grown in greenhouses covered with energy saving double layer materials, Acta Hortic. 148 (1984) 555-559.

[24] Takakura T., Jordan K.A., Boyd L.L, Dynamic simulation of plant growth and environment in the greenhouse, Trans. ASAE 14 (1971) 964-971.

[25] Van Bavel C.H.M., Takakura T., Bot G.P.A., Global comparison of three greenhouse climate models, Acta Hortic. 174 (1985) 21-33.

[26] Wang S., Zhu S., Deltour J., Simulation and measurement of tunnel greenhouse climate, Trans. CSAE 13 (1997) 139-144.

[27] Zhang Y., Gauthier L., de Halleux D., Dansereau B., Gosselin A., Effect of covering materials on energy consumption and greenhouse microclimate, Agric. For. Meteorol. 82 (1996) 227-244.

\section{Appendix A: Radiation sources}

\begin{tabular}{ll}
\hline Term & Wavebands \\
\hline Solar UV & $300-380 \mathrm{~nm}$ \\
Solar visible & $380-760 \mathrm{~nm}$ \\
Solar infrared & $760-2500 \mathrm{~nm}$ \\
Total solar & $300-2500 \mathrm{~nm}$ \\
Photosynthetically active & $400-700 \mathrm{~nm}$ \\
Far infrared & $2.5-40 \mu \mathrm{m}$ \\
\hline
\end{tabular}




\section{Appendix B: Nomenclature}

$A_{1} \quad$ greenhouse ground area, $\mathrm{m}^{2}$

$\mathrm{C}_{\mathrm{a}} \quad$ heat capacity of the air, $\mathrm{J} \mathrm{m}^{-3} \mathrm{~K}^{-1}$

$\mathrm{D} \quad$ conductive flux density, $\mathrm{W} \mathrm{m}^{-2}$

$\mathrm{L} \quad$ latent heat flux density, $\mathrm{W} \mathrm{m}^{-2}$

LAI leaf area index

$\mathrm{M}_{v} \quad$ vegetation surface mass density, $\mathrm{kg} \mathrm{m}^{-2}$

$\mathrm{P}_{\mathrm{v}} \quad$ portion of ground area covered by crops

$\mathrm{Q}_{\text {in }} \quad$ input heat flux density, $\mathrm{W} \mathrm{m}^{-2}$

$\mathrm{R} \quad$ thermal radiative flux density, $\mathrm{W} \mathrm{m}^{-2}$

$\mathrm{S} \quad$ solar radiative flux density, $\mathrm{W} \mathrm{m}^{-2}$

$\mathrm{t}$ time, $\mathrm{s}$

$\mathrm{T}$ temperature, $\mathrm{K}$

$\mathrm{V} \quad$ convective flux density, $\mathrm{W} \mathrm{m}^{-2}$

VOL greenhouse volume, $\mathrm{m}^{3}$ $\lambda \quad$ wavelenth, $\mathrm{nm}$

$\rho \quad$ reflectance

$\tau \quad$ transmittance

Subscripts

c cover

e exterior air

i interior air

r sky

s soil surface

s1 first soil layer

s2 second soil layer

s3 third soil layer

ss subsoil

$\mathrm{v} \quad$ vegetation 